\title{
PERTUMBUHAN DAN PRODUKSI KEDELAI VARIETAS ANJASMORO PADA TANAH SALIN
}

\author{
GROWTH AND PRODUCTION OF SOYBEAN VARIETIES ANJASMORO ON SALIN LAND
}

\author{
Usnawiyah $^{1}$ ), Delvian ${ }^{2}$ ), T. Sabrina ${ }^{2}$ )
}

\begin{abstract}
Increased soybean production is competing with the extension of the use of agricultural land for nonagricultural needs. Therefore the future expansion of agricultural land can only use marginal lands such as peatlands, wetlands and tidal lands. This paper discusses the growth and production of soybean varieties Anjasmoro in saline environments. Varieties Anjasmoro have total leaf area and the percentage ratio of the canopy which is not significantly different from the other varieties tested except Kipas Merah. In the production of components, seed weight Anjasmoro 100 seeds varieties including higher and statistically the same as the varieties Kipas Putih dan Kipas Merah.
\end{abstract}

Key words : Soybean, Anjasmoro varieties, salinity, saline soil

\section{PENDAHULUAN}

Kedelai termasuk jenis kacang-kacangan penting terutama untuk pemenuhan kebutuhan akan protein nabati. Kebutuhanini pun semakin meningkat seiring bertambahnya jumlah penduduk yang tidak dibarengi ketersediaannya dipasaran. Adisarwanto (2008), menyebutkan bahwa produksi kedelai nasional hanya sebesar 1,3 ton/ha pada tahun 2007 dan di Aceh Utara produksi kedelai pun masih dibawah produksi nasional yaitu sebesar 1,2 ton/ha pada tahun 2006 (BPS, 2008). Sedangkan kebutuhan kedelai tiap tahunnya mencapai angka 2 juta ton/ha. Tentu saja untuk memenuhi angka kebutuhan tersebut, pemerintah mengimpor hampir sekitar 1,2 juta ton/ha atau sekitar $60 \%$ dari kebutuhan nasional.

Pemenuhan kebutuhan terhadap kedelai dapat dicapai melalui peningkatan produksi secara nasional baik melalui ekstensifikasi maupun intensifikasi. Perluasan lahan pertanian dimasa mendatang hanya dapat menggunakan lahan-lahan marginal seperti lahan gambut, lahan rawa dan lahan pasang surut. Lahan pasang surutdi Indonesia diperkirakan sekitar 33 juta hektar yang tersebar di Sumatera, Kalimantan, Sulawesi dan Irian Jaya. Dari jumlah tersebut sekitar 6 juta hektar berpotensi untuk pengembangan pertanian (Hidayat, 2002). Namun, produktifitas lahan masih sangat rendah dikarenakan tingkat salinitas yang tinggi (Marsi et al., 2003). Departemen Pertanian tahun 2005 menunjukkan pula bahwa kadar garam di lapisan permukaan lahan sawah yang terendam air laut di daerah Aceh mencapai 8-10 dS/m.

Peningkatan produksi tanaman pada lahan yang telah mengalami cekaman salinitas dapat dilakukan melalui pemanfaatan FMA. Hal ini karena adanya jaringan hifa eksternal yang lebih halus dari bulu-bulu akar sehingga dapat memperluas bidang serapan air dan hara (Kilham, 1994). Pemilihan varietas yang tepat untuk ditanami pada lahan salin juga sangat menentukan tingkat produktifitas lahan tersebut. Namun, sampai ini belum diketahui varietas tanaman kedelai yang betul-betul toleran terhadap salinitas. Dalam tulisan ini, varietas yang dibahas adalah pertumbuhan dan produksi varietas Anjasmoro akibat pemberian fungi mikoriza pada tanah salin.

\section{BAHAN DAN METODE PENELITIAN}

Bahan yang digunakan adalah tanah salin bagian top soil yang dimasukkan ke dalam polybag seberat $10 \mathrm{~kg}$. Benih kedelai terdiri dari varietas Kipas Merah, Kipas Putih, Anjasmoro dan varietas Willis. Bahan lain berupa FMA, pupuk kandang, Urea, TSP, KCl, dan insektisida Furadan.

Penelitian ini menggunakan rancangan acak kelompok pola faktorial yang terdiri dari faktor varietas dan pemberian FMA. Varietas yang

1) Staf Pengajar Fakultas Pertanian Universitas Malikussaleh

2) Staf Pengajar Fakultas Pertanian Pasca Sarjana Universitas Sumatera Utara 
digunakan adalah Kipas Merah, Kipas Putih, Willis dan Anjasmoro. Pemberian FMA terdiri dari 2,5; 5 dan 7,5 gr mikofer/polybag. Peubah pengamatan meliputi luas daun, rasio tajuk akar dan berat 100 biji.

\section{HASIL DAN PEMBAHASAN}

\section{Pertumbuhan Tanaman Kedelai Varietas Anjasmoro}

Data hasil pengamatan total luas daun dan rasio tajuk akar pada umur 9 minggu setelah tanam (MST) menunjukkan pengaruh nyata terhadap varietas yang dicobakan.

Hasil pada Tabel 1 menunjukkan bahwa varietas Anjasmoro memiliki total luas daun yang tidak berbeda nyata dengan varietas lain yang dicobakan kecuali Kipas Merah. Demikian juga halnya dengan persentase rasio tajuk akar varietas Anjasmoro yang tidak berbeda nyata dengan varietas Willis dan Kipas Merah. Persentasenya pun cenderung lebih kecil bila dibandingkan varietas Kipas Putih.

Perbedaan keragaan diantara varietas ini diduga disebabkan oleh faktor genetis yang merupakan salah satu faktor penentu pertumbuhan dan perkembangan tanaman selain faktor lingkungan. Kenyataan bahwa varietas yang digunakan bukanlah varietas yang sengaja dibentuk bagi tanah salin merupakan faktor pembatas terhadap perbedaan respon setiap varietas tersebut.

Dalam hal ini varietas Anjasmoro menunjukkan mekanisme pertahanan secara fisiologi dengan menurunkan potensial osmotis tanpa kehilangan turgor. Laju penyesuaian ini relatif tergantung dari spesies tanaman (Maas dan Nieman, 1978 dalam Basri, H., 1991). Perubahan ukuran seperti mengecilnya daun, berkurangnya jumlah stomata per satuan luas daun serta lignifikasi akar juga dijumpai sebagai bentuk adaptasi morfologi pada tanaman di tanah salin (Harjadi dan Yahya, 1988 dalam Sipayung., 2003).

\section{Produksi Tanaman Kedelai Varietas Anjasmoro}

Pada komponen produksi, berat biji 100 biji varietas Anjasmoro termasuk lebih tinggi dan secara statistik sama dengan varietas Kipas Putih dan Kipas Merah. Ini mengindikasikan bahwa varietas ini termasuk varietas yang toleran terhadap kondisi lingkungan salinitas tinggi. Dalam hal ini, varietas tersebut diduga secara genetis memiliki kemampuan yang lebih baik pada kondisi ini.

Kemampuan varietas ini untuk berproduksi lebih tinggi terkait dengan mekanisme toleransi yang dimiliki terhadap cekaman salinitas. Hal ini dimungkinkan oleh adanya kadar gula yang tergolong tinggi dari varietas tersebut. Tanaman melakukan penyesuaian melalui penyerapan ataupun dengan pengakumulasian ion-ion dan sintesis senyawa-senyawa organik di dalam sel. Mekanisme ini cukup menurunkan potensial osmotic sel dan meningkatkan turgor yang diperlukan bagi pertumbuhan (Maas dan Nieman dalam Basri, 1991).

Tabel 1. Total Luas Daun (cm2) dan Rasio Tajuk Akar (\%) BeberapaVarietas yang diteliti.

\begin{tabular}{|l|l|l|l|}
\hline Varietas & Total Luas Daun $\left(\mathrm{cm}^{2}\right)$ & Rasio Tajuk Akar $(\%)$ & Berat $100 \mathrm{biji}(\mathrm{g})$ \\
\hline Anjasmoro & $35,21 \mathrm{~b}$ & $7,40 \mathrm{~b}$ & $8,69 \mathrm{a}$ \\
\hline Willis & $33,70 \mathrm{~b}$ & $5,99 \mathrm{~b}$ & $6,58 \mathrm{~b}$ \\
\hline Kipas Putih & $41,91 \mathrm{a}$ & $10,25 \mathrm{a}$ & $7,61 \mathrm{a}$ \\
\hline Kipas Merah & $35,88 \mathrm{~b}$ & $7,45 \mathrm{~b}$ & $9,03 \mathrm{a}$ \\
\hline
\end{tabular}


Keterangan : Angka yang diikuti oleh huruf yang sama pada baris atau kolom yang sama tidak berbeda nyata pada taraf uji Duncan 5\%.

\section{KESIMPULAN}

1. Varietas Anjasmoro memiliki total luas daun dan persentase rasio tajuk yang tidak berbeda nyata dengan varietas lain yang dicobakan kecuali Kipas Merah.

2. Pada komponen produksi, berat biji 100 biji varietas Anjasmoro termasuk lebih tinggi dan secara statistik sama dengan varietas Kipas Putih dan Kipas Merah.

\section{DAFTAR PUSTAKA}

Adisarwanto. T. 2008. Budidaya Kedelai Tropika. Penebar Swadaya. Jakarta.

Basri, H. 1991. Pengaruh Stres Garam Terhadap Pertumbuhan dan Produksi Empat Varietas Kedelai. Thesis Program Pascasarjana IPB, Bogor.

BPS (Badan Pusat Statistik). 2008. Aceh Utara Dalam Angka. Badan Pusat Statistik. Kabupaten Aceh Utara.
Departemen Pertanian. 2005. Bertanam Padi Di Tanah Bencana. http;//www.Pustaka_Deptan.go.id.

Harjadi, S.S., dan Yahya, S. 1988. Fisiologi Stress Lingkungan. Pusat antar Universitas. Institut Pertanian Bogor. Bogor.

Hidayat. 2002. Potensi Lahan Basah. Pertanian Universitas Tanjung Pura. Akta Agrosia. Vol. 5: (1:60-67)

Killham, K. 1994. Soil Ecology. Cambridge University Press.

Marsi. Sabaruddin, N. Govar. S.J. Priatna dan R. Suwignyo. 2003. Salinitas dan Oksidasi Pirit pada Lahan Pasang Surut Pantai Timur Sumatera Selatan. Jurusan Ilmu Tanah. Universitas Sriwijaya.

Sipayung, P. 2003. Stress Garam dan Mekanisme Toleransi Tanaman. Fakultas Pertanian. Jurusan Budidaya Pertanian. Universitas Sumatera Utara, Medan. 